Pesq. Vet. Bras. 35(4):337-343, abril 2015 DOI: $10.1590 / \mathrm{S} 0100-736 \mathrm{X} 2015000400004$

\title{
Histopathological, immunohistochemical, and molecular study of BHV-5 infection in the central nervous system of experimentally infected calves ${ }^{1}$
}

\author{
Didier Q. Cagnini², Paulo H.J. Cunha ${ }^{3}$, José C.F. Pantoja ${ }^{4}$, Peres R. Badial², \\ José Paes de Oliveira-Filho ${ }^{2}$, João P. Araújo-Junior ${ }^{5}$, Amauri A. Alfieri ${ }^{5}$ \\ and Alexandre S. Borges ${ }^{2 *}$
}

\begin{abstract}
Cagnini D.Q., Cunha P.H.J., Pantoja J.C.F., Badial P.R., Oliveira-Filho J.P., AraújoJunior J.P., Laufer-Amorim R. \& Borges A.S. 2015. Histopathological, immunohistochemical, and molecular study of BHV-5 infection in the central nervous system of experimentally infected calves. Pesquisa Veterinária Brasileira 35(4):337-343. Departamento de Clínica Veterinária, Faculdade de Medicina Veterinária e Zootecnia, Universidade Estadual Paulista "Júlio de Mesquita Filho", Unesp-Botucatu, Distrito de Rubião Júnior s/n, Botucatu, SP 18618-970, Brazil. E-mail: asborges@fmvz.unesp.br

Bovine meningoencephalitis caused by BHV-5, a double-stranded DNA enveloped virus that belongs to the family Herpesviridae and subfamily Alphaherpesvirinae, is an important differential diagnosis of central nervous diseases. The aim of this study was to describe the histological changes in the central nervous system of calves experimentally infected with BHV-5 and compare these changes with the PCR and IHC results. Formalin-fixed paraffin-embedded central nervous system samples from calves previously inoculated with BHV-5 were microscopically evaluated and tested using IHC and PCR. All the animals presented with nonsuppurative meningoencephalitis. From 18 evaluated areas of each calf, 32.41\% and $35.19 \%$ were positive by IHC and PCR, respectively. The telencephalon presented more accentuated lesions and positive areas in the PCR than other encephalic areas and was the best sampling area for diagnostic purposes. Positive areas in the IHC and PCR were more injured than IHC and PCR negative areas. The animal with neurological signs showed more PCR- and IHC-positive areas than the other animals.
\end{abstract}

INDEX TERMS: Bovine herpesvirus 5, diseases of cattle, meningoencephalitis, neuropathology.

RESUMO.- [Estudo histopatológico, imuno-histoquímico e molecular da infecção por BHV-5 no sistema nervoso central de bovinos experimentalmente infectados.] A meningoencefalite bovina causada pelo BHV-5, um vírus DNA fita dupla envelopado que pertence à família Herpes-

\footnotetext{
${ }^{1}$ Received on September 5, 2014.

Accepted for publication on April 6, 2015

${ }^{2}$ Departamento de Clínica Veterinária, Faculdade de Medicina Veterinária e Zootecnia (FMVZ), Univ. Estadual Paulista (Unesp), Distrito de Rubião Júnior s/n, Botucatu, SP 18618-970, Brazil. Bolsista de Produtividade em Pesquisa do CNPq; *Corresponding author: asborges@fmvz.unesp.br

${ }^{3}$ Departamento Medicina Veterinária, Escola de Veterinária e Zootecnia, Universidade Federal de Goiás (UFG), Campus Samambaia (Campus II), Cx. Postal 131, Goiânia, GO 74001-970, Brazil.

${ }^{4}$ Departamento de Higiene Veterinária e Saúde Pública, FMVZ-Unesp, Distrito de Rubião Júnior s/n, Botucatu, SP.

${ }^{5}$ Departamento de Microbiologia e Imunologia, Instituto de Biociências de Botucatu, Unesp, Distrito de Rubião Júnior s/n, Botucatu, SP.
}

viridae e subfamília Alphaherpesvirinae, é um importante diagnóstico diferencial das doenças do sistema nervoso central. 0 objetivo deste estudo foi descrever as alterações histológicas no sistema nervoso central de bovinos experimentalmente infectados com BHV-5 e comparar estas alterações com os resultados de imunoistoquímica (IHQ) e PCR. Amostras do sistema nervoso central de bezerros previamente inoculados com BHV-5 foram microscopicamente avaliadas e submetidas à IHQ e PCR. Todos os animais apresentaram meningoencefalite não-supurativa. Das 18 áreas avaliadas de cada bezerro, $32,41 \%$ e $35,13 \%$ foram positivas na IHQ e PCR, respectivamente. 0 telencéfalo apresentou lesões mais acentuadas e foi mais positivo na PCR do que as demais áreas encefálicas e se apresentou como a melhor área para coleta de material para o diagnóstico. As áreas positivas na IHQ e na PCR apresentaram lesões mais acentuadas do que as áreas negativas para as mesmas téc- 
nicas. 0 animal com sinais neurológicos apresentou mais áreas positivas para PCR e IHQ do que os demais animais.

TERMOS DE INDEXAÇÃO: Herpesvirus bovino 5, doenças de bovinos, meningoencefalite, neuropatologia.

\section{INTRODUCTION}

BHV-5 is a double-stranded DNA enveloped virus that belongs to the family Herpesviridae, subfamily Alphaherpesvirinae, and genus Varicellovirus. This virus is involved in cases of nonsuppurative meningoencephalitis in cattle (Roizmann et al. 1992). Meningoencephalitis mainly occurs in calves and causes individual deaths or outbreaks with low morbidity and high mortality (Rissi et al. 2006, Rissi et al. 2008). The disease has no seasonal pattern or predilection for breed or gender (Barros et al. 2006). Outbreaks of meningoencephalitis have been reported to be associated with stress, such as weaning, vaccination, transport, or feeding changes (Rissi et al. 2008).

The presumptive diagnosis is based on clinical, epidemiological, macroscopic, and microscopic findings. A definitive diagnosis can be made via virus isolation from cell cultures combined with other techniques such as immunoperoxidase staining (Oldoni et al. 2004), restriction endonuclease digestion (Meyer et al. 2001), or polymerase chain reaction (PCR) (Sá E Silva et al. 2007). However, virus isolation is not always possible due to confounding factors, such as the distance from the farm to the laboratories, the time of death, and the sample collection and isolation procedures (Franco e Roehe 2007). In these cases, immunohistochemistry (IHC) and PCR are good diagnostic tools and can be performed using formalin-fixed, paraffin-embedded (FFPE) tissues (Meyer et al. 2001, Ferrari et al. 2007).

The aim of this study was to describe the distribution and severity of the histopathological changes in the CNS of calves experimentally infected with BHV-5 as well as to compare these changes with the PCR and IHC results. For this purpose, FFPE CNS tissues from calves previously inoculated with BHV-5 (Cunha 2010) were microscopically evaluated and tested using IHC and PCR.

\section{MATERIALS AND METHODS}

\section{Animals and samples}

Six 10-month-old calves referred to as Animals 1 through 6 were inoculated intranasally with $0.5 \mathrm{ml}$ of a BHV- 5 suspension in each nostril (total dose of $10^{6.5} \mathrm{TCID}_{50}$ ). A previously isolated BHV-5 AA PAR strain (Souza et al. 2002) and bovine herpesvirusseronegative (virus neutralization technique) calves were used. Animals were monitored daily for 30 days post infection (PI). The animals were necropsied after the experimental period, after natural death or after euthanasia. Eighteen neural tissue areas were collected, fixed in $10 \%$ buffered neutral formalin, and examined for the presence of lesions and BHV-5 antigens and DNA. Bilateral samples of the olfactory bulb; frontal, parietal and occipital cortices; basal nucleus; and thalamus were collected. The midbrain, pons, medulla oblongata, cervical spinal cord, cerebellum, and Gasserian ganglia (trigeminal ganglia) were also collected. The procedures were previously approved by the Universidade Estadual Paulista (UNESP) Institutional Animal Care and Use Committee $(91 / 2009)$.

\section{Histopathology}

Sections from the brain, spinal cord, and Gasserian ganglia were sectioned ( $5 \mu \mathrm{m}$ thick) and stained with hematoxylin and eosin. All 108 CNS samples were evaluated for 12 parameters: vascular changes (edema, congestion, and hemorrhagic changes), nervous tissue changes (number and degree of perivascular cuffing, neuronal necrosis, intranuclear inclusion bodies, diffuse or focal gliosis, malacia with presence of Gitter cells, inflammatory foci in the neuropil, and neuronophagia) and leptomeningeal changes (meningitis) (Rissi et al. 2006, Sant'ana et al. 2009). All parameters were scored as 0 (absence), 1 (mild), 2 (moderate), or 3 (severe). The lesions were scored as mild, moderate, or severe when $0-25 \%, 25-50 \%$, or more than $50 \%$ of the section was affected, respectively. Intranuclear inclusion bodies were classified as either present or absent.

\section{Immunohistochemistry}

Tissues were sectioned ( $5 \mu \mathrm{m}$ thick), deparaffinized, rehydrated, and immersed in $3 \%$ hydrogen peroxide solution in methanol for $20 \mathrm{~min}$. The sections were digested with proteinase $\mathrm{K}(25 \mu \mathrm{g} /$ $\mathrm{ml}$ in TE buffer, $\mathrm{pH} 8.0$ ) for $15 \mathrm{~min}$ at $37^{\circ} \mathrm{C}$. Non-specific binding was blocked with $3 \%$ skim milk in phosphate-buffered saline for $1 \mathrm{~h}$, and endogenous biotin was blocked as recommended by the manufacturer ${ }^{6}$. The $2 \mathrm{~F} 9$ monoclonal antibody against BHV-5gC protein(Oldoni et al. 2004) (diluted 1:200) was added to the tissue sections, which were incubated for $2 \mathrm{~h}$ at $37^{\circ} \mathrm{C}$. A biotinylated goat anti-mouse antibody ${ }^{7}$ was used as the secondary antibody. All washes were performed with TE buffer, $\mathrm{pH}$ 7.4. The peroxidase substrate solution $\left(3,3^{\prime}\right.$ diaminobenzidinetetrahydrochloride; Dako) was diluted as recommended by the manufacturer, and the sections were counter-stained with Harris hematoxylin. For each IHC test, negative (uninfected calf, PCR-negative sections, and no primary antibody) and positive (confirmed natural clinical case with a PCR-positive reaction) sections were included as controls. The IHC results were classified as either negative or positive, and positive sections were subclassified as 1-5 cells/section ( + ), 1-3 foci/section (++), 4-10 foci/section (+++) or more than 10 foci/ section (++++), as previously described (Meyer et al. 2001).

\section{DNA isolation and PCR assay}

Total DNA was isolated from CNS samples using a commercial $\mathrm{kit}^{8}$ as recommend by the manufacturer, and stored at $-20^{\circ} \mathrm{C}$ until processing. All of the handling, extraction, and amplification procedures were performed in separate laboratories using disposable tips with barrier protection.

PCR was performed as previously described (Claus et al. 2005) and $\beta$-actin (GenBank, NC_007326.4) was used as internal control for the evaluation of DNA extraction efficiency and DNA integrity in all of the PCR reactions. The primer sets used in the PCR, which amplified a 159-bp fragment of the BHV-5gC gene (GenBank, U35883.1) and an 87-bp fragment of the Bos Taurus $\beta$-actin gene, are presented in Table 1. Total DNA extracted from BHV-5 AA PAR

\footnotetext{
${ }^{6}$ Biotin Blocking System, Dako Corporation, Carpinteria, CA, USA.

${ }^{7}$ Biotinylated goat anti-mouse antibody, Dako Corporation, Glostrup, Denmark.

${ }^{8}$ QIAamp DNA FFPE Tissue Kit, Qiagen, Valencia, CA, USA.
}

Table 1. Nucleotide sequences of primers used for the BHV-5 PCR

\begin{tabular}{lcc}
\hline Primersname & Primer sequence $\left(5^{\prime}-3^{\prime}\right)$ & Use Position \\
\hline B5* & CGGACGAGACGCCCTTGG & nt 322-339 \\
Bcon* & AGTGCACGTACAGCGGCTCG & nt 461-480 \\
ß-actinForward & TCATGAAGATCCTCACGGAGCGT & nt 595-617 \\
ß-actin Reverse & AGCAGAGCTTCTCCTTGATGTCAC & nt 658-681
\end{tabular}


strain and nuclease-free water were used as positive and negative controls, respectively, in all the PCR assays.

Each $25 \mu \mathrm{l}$ PCR reaction contained $0.4 \mu \mathrm{M}$ of each primer, $5 \mu \mathrm{l}$ of DNA template, $12.5 \mu \mathrm{l}$ of GoTaq Green Master Mix ${ }^{9}, 8 \%$ dimethyl sulfoxide ${ }^{10}$ and nuclease-free water. The following amplification conditions were used: an initial denaturation at $95^{\circ} \mathrm{C}$ for $7 \mathrm{~min} ; 40$ cycles of $94^{\circ} \mathrm{C}$ for $40 \mathrm{~s}, 57.8^{\circ} \mathrm{C}$ for $1 \mathrm{~min}$, and $72^{\circ} \mathrm{C}$ for $1 \mathrm{~min}$; and a final extension at $72^{\circ} \mathrm{C}$ for $5 \mathrm{~min}$.

The PCR products were analyzed via 1.5\% agarose gel electrophoresis and visualized using Gel Red $^{11}$. The molecular weights were estimated by comparison with a known marker (100 bp ladder $)^{12}$. The gels were documented with an ImageQuant System ${ }^{13}$.

\section{Sequences analysis}

The BHV-5gC gene amplified products were purified using a commercial $\mathrm{kit}^{14}$. The sequencing reactions were performed ${ }^{15}$ and compared with the BHV-5gC sequence deposited in GenBank (U35883.1) to confirm the PCR specificity.

\section{Statistical analysis}

CNS areas were arbitrarily grouped into region 1 (olfactory bulb, telencephalon and basal nuclei) and 2 (thalamus, midbrain, pons, and medulla oblongata). All of the results were submitted to descriptive analysis (presented as arithmetical mean and standard deviation). However, for statistical purposes, the sum of the lesions scores were transformed to a $\log _{10}$ scale and were presented as geometric mean with $95 \%$ confidence intervals (CI). ANO$\mathrm{VA}^{16}$ was used to compare the differences of the mean lesions score among animals and brain sections. Similar models were used to compare the mean score of the grouped lesions based on the PCR or IHC results (positive/negative). A compound symmetry covariance structure was initially included in the models to compare the clustering resulting from multiple observations within the same animal. Nonetheless, the intraclass correlation was negligible, and the final models assuming independence among the observations provided the best fit for the data.

Logistic regression models ${ }^{16}$ were constructed to estimate the odds of a positive PCR or IHC result among the animals and brain sections. The $\kappa$ coefficient $^{16}$ was used to estimate the agreement between the IHC and PCR results. Chi-square or Fisher's exact tests ${ }^{16}$ were used to assess the association between the neurological symptoms and the PCR or IHC results. P values less than 0.05 were considered significant.

\section{RESULTS}

Of the six animals experimentally inoculated with BHV-5, one animal (designated Animal 1) presented with neurological abnormalities, and was euthanized 12 days post infection (PI) after a clinical evolution of 1 day. A second animal (Animal 2) abruptly died 21 days PI. The other four animals (Animals 3-6) did not present with any neurological abnormalities and were euthanized 30 days PI. All animals were necropsied immediately after death(Cunha 2010).

\footnotetext{
${ }^{9}$ GoTaq Green Master Mix, Promega, Madison, WI, USA.

${ }^{10}$ Dimethyl sulfoxide, Sigma, St Louis, MO, USA.

${ }^{11}$ GelRed $^{\mathrm{TM}}$, Biotium Inc., Hayward, CA, USA.

12100 bp ladder, NorgenBiotek, Ontario, Canada.

${ }^{13}$ ImageQuant ${ }^{\circledR}$, Ge Healthcare Life Sciences, Uppsala, Sweden.

${ }^{14}$ Invisorb Fragment CleanUp, Invitrogen, Carlsbad, CA, USA.

${ }^{15}$ ABI 3500 Sequence Detection System, Applied Biosystems, Foster City, CA, USA.

${ }^{16}$ PROC MIXED, SAS Institute 2009.
}

\section{Histopathology}

Nonsuppurative meningoencephalitis was observed in all animals and varied in intensity by animal and brain section. The severity of the lesions varied by location, with the frontal cortex containing the most severe lesions, followed by the thalamus, parietal and occipital cortices, olfactory bulb, and basal nucleus. The less-damaged areas included the midbrain, pons, and medulla oblongata. No lesions were observed within the cervical spinal cord and Gasserian ganglia.

The histopathological changes, in decreasing order of severity, included mononuclear perivascular cuffing (Fig.1), edema, diffuse gliosis, congestion, focal gliosis, neuronal necrosis, neuronophagia, inflammatory foci, meningitis, hemorrhage, and malacia.

Mononuclear perivascular cuffing was the most severe change and presented the greatest mean in the frontal cortex $(1.83 \pm 0.55)$, thalamus $(1.83 \pm 0.8)$, basal nucleus $(1.5 \pm 0.76)$, and parietal cortex $(1.17 \pm 0.9)$. Edema was mainly detected in the frontal $(2.0 \pm 0.58)$, parietal $(1.58 \pm 0.76)$, and occipital cortices $(1.50 \pm 0.96)$; olfactory bulb $(1.33 \pm 0.75)$, and thalamus $(1.17 \pm 1.07)$.

Neuronal necrosis was detected mainly in the frontal $(1.58 \pm 0.86)$, parietal $(1.42 \pm 0.95)$, and occipital cortices $(1.25 \pm 1.0)$ and in the thalamus $(0.92 \pm 0.76)$. Increased neuronal necrosis was observed in Animals 1 and 2 compared with the other animals. In Animal 1, five different areas with moderate malacia were found, whereas only one area was found in Animal 2. Mild areas of malacia were observed in the brains of Animals 3 and 4.

Eosinophilic intranuclear inclusion bodies were found within neurons and glial cells in 7 of the 108 sections examined, and these inclusions were mainly associated with areas with malacia. Mononuclear meningitis was observed in $17.5 \%$ of the brain sections analyzed.

Histopathological lesions were most severe in Animal1 compared with Animals 4, 5 and $6(P<0.02$ for all comparisons). The adjusted mean of the lesions for region 1 (7.47; $\mathrm{CI}=6.54-8.52)$ was significantly greater $(P<0.001)$ than region 2 (5.89; $\mathrm{CI}=4.89-7.10)$. Moreover, there were no significant correlations $(P=0.205)$ between the CNS regions and

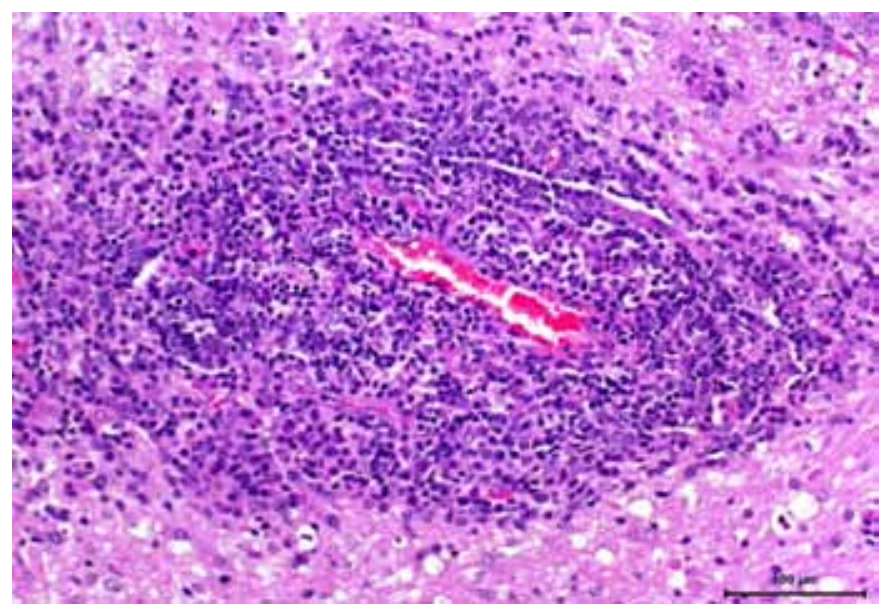

Fig.1. Cerebral cortex, Animal 1. Perivascular cuffing with more than 10 layers of mononuclear inflammatory cells. Hematoxylin and eosin, Bar $=100 \mu \mathrm{m}$. 
the animals, indicating that the affected areas were consistent among the animals. The adjusted geometric mean of the lesions by animal, CNS region (1 and 2), PCR and IHC result (positive/negative) are presented in Figure 2.

\section{Immunohistochemistry and PCR}

Thirty-five $(32.4 \%)$ areas were positive in the IHC for BHV-5 glycoprotein C (gC) (Table 2). Animal 1 presen-

Table 2. Immunohistochemistry and PCR results in different brain regions of six calves experimentally infected with BHV-5*

\begin{tabular}{|c|c|c|c|c|c|c|c|c|c|c|c|c|}
\hline \multirow[t]{2}{*}{ Calf } & \multicolumn{2}{|c|}{1} & \multicolumn{2}{|c|}{2} & \multicolumn{2}{|c|}{3} & \multicolumn{2}{|c|}{4} & \multicolumn{2}{|c|}{5} & \multicolumn{2}{|c|}{6} \\
\hline & IHC & $\overline{\mathrm{PCR}}$ & $\overline{\mathrm{IHC}}$ & $\overline{\mathrm{PCR}}$ & $\mathrm{IHC}$ & $\overline{\mathrm{PCR}}$ & $\mathrm{IHC}$ & $\overline{\text { PCR }}$ & $\mathrm{IHC}$ & $\overline{\mathrm{PCR}}$ & $\mathrm{IHC}$ & PCR \\
\hline LOB & + & + & + & + & - & - & + & - & - & - & - & - \\
\hline ROB & ++ & + & + & + & - & - & - & - & - & - & - & - \\
\hline LFC & ++++ & + & - & + & - & + & + & + & - & + & - & - \\
\hline RFC & ++++ & + & + & + & - & + & - & + & - & - & - & - \\
\hline LPC & - & + & + & + & + & - & - & - & + & - & - & - \\
\hline RPC & +++ & + & - & + & - & - & - & - & - & - & - & - \\
\hline LOC & ++++ & - & - & + & - & - & - & - & - & - & - & + \\
\hline ROC & ++ & + & - & + & - & + & - & - & - & + & - & - \\
\hline LBN & ++ & + & + & - & - & - & - & + & - & - & - & + \\
\hline RBN & + & + & - & + & + & - & - & - & + & - & - & - \\
\hline LT & ++++ & + & + & - & + & - & + & - & + & - & + & - \\
\hline RT & +++ & + & - & + & + & - & + & - & + & - & + & - \\
\hline M & + & - & - & - & + & - & - & - & - & - & - & - \\
\hline $\mathrm{P}$ & + & + & - & + & - & - & - & - & - & - & - & + \\
\hline B & + & - & - & - & - & - & - & - & - & - & - & + \\
\hline GG & - & + & - & - & - & - & - & - & - & - & - & - \\
\hline C & - & - & - & - & - & - & - & - & - & + & - & - \\
\hline $\mathrm{CSC}$ & - & + & - & - & - & - & - & - & - & - & - & - \\
\hline Total & 14 & 14 & 6 & 11 & 5 & 3 & 4 & 3 & 4 & 3 & 2 & 4 \\
\hline$\%$ & 77.8 & 77.8 & 33.3 & 61.1 & 27.8 & 16.7 & 22.2 & 16.7 & 22.2 & 16.7 & 11.1 & 22.2 \\
\hline
\end{tabular}

*IHC (- negative; + 1-5 cells/section; ++ 1-3 foci/section; +++ 4-0 foci/ section; ++++ >10 foci/section). PCR (- negative; + positive). Different letters represent statistical differences using the same diagnostic tool $(\mathrm{p}<0.05)$. $(\mathrm{L}=$ left; $\mathrm{R}=$ right; $\mathrm{OB}=$ olfactory bulb; $\mathrm{FC}=$ frontal cortex; $\mathrm{PC}=$ parietal cortex; $\mathrm{OC}=$ occipital cortex; $\mathrm{BN}=$ basal nucleus; $\mathrm{T}=$ thalamus; $\mathrm{M}=$ Midbrain; $\mathrm{P}=$ pons; $\mathrm{B}=$ medulla oblongata; $\mathrm{C}=$ cerebellum; $\mathrm{CSC}=$ cervical spinal cord; $\mathrm{GG}=$ Gasserian ganglia $)$.

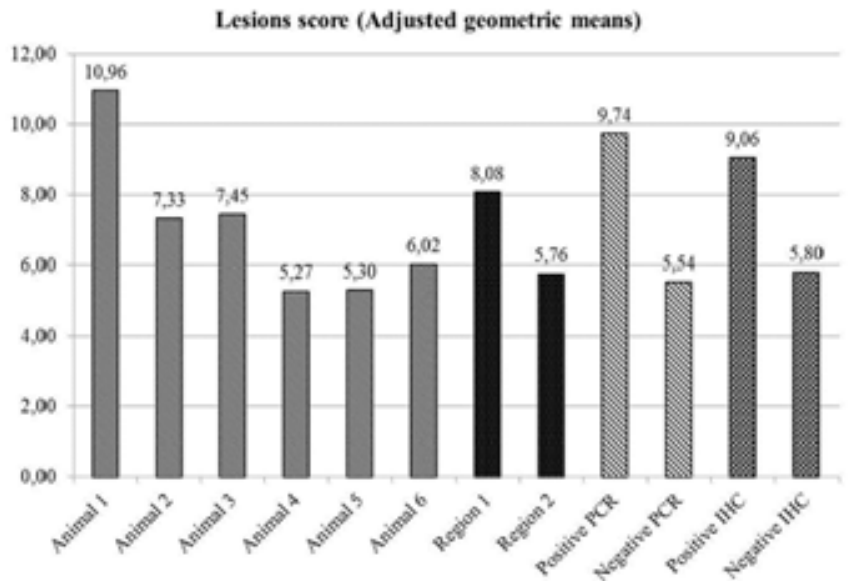

Fig.2. Adjusted geometric means* of lesions distributed by animal (1 to 6 ), CNS region (1 and 2), and the PCR and IHC results (positive/negative). * The scores of the lesions were transformed to a $\log _{10}$ scale for analysis and are presented as the geometric mean with 95\% confidence intervals (CI). Region 1 included the olfactory bulb and telencephalon; region 2 included the basal nucleus, thalamus, midbrain, pons, and medulla oblongata.

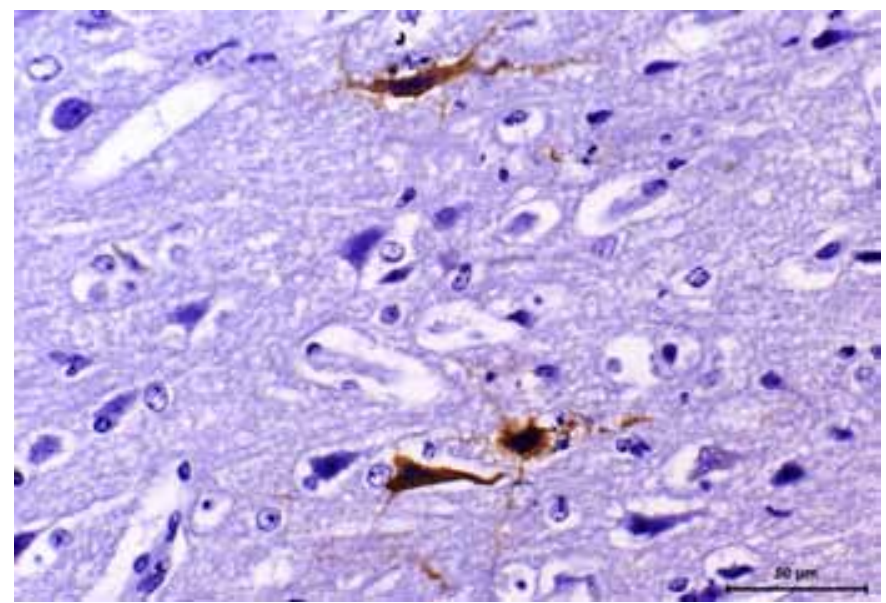

Fig.3. Cerebral cortex, Animal 1. Positive BHV-5 gC immunohistochemistry reaction in the left frontal cortex. Hematoxylin and eosin counterstaining, $\mathrm{Bar}=50 \mu \mathrm{m}$.

ted with more IHC-positive areas than the other animals $(P<0.05)$. The odds of an IHC-positive result for Animal 1 were 20.9 times greater than Animal 2 ( $\mathrm{CI}=2.15-204.5$ ), 27.9 than Animal 3 ( $\mathrm{CI}=2.8-277.9), 38.4$ than Animals 4 and 5 (CI=3.74-395.3) and 90.8 than Animal 6 (CI=7.34->999.9). The mean of the lesions in the IHC-positive areas (9.06) was greater than the IHC-negative areas $(5.8)(P<0.001)$. There was no significant difference in the number of IHC-positive areas between CNS regions 1 and $2(P=0.13)$. A positive IHC reaction to $\mathrm{BHV}-5 \mathrm{gC}$ in the left frontal cortex of Animal 1 is shown in Figure 3.

Thirty-eight (35.2\%) CNS areas were PCR positive for BHV-5 gC (Table 1). The mean of the lesions was greater in PCR-positive areas than in the PCR-negative areas $(P<0.0001)$. There was no difference between Animals 1 and 2 regarding the odds of presenting positive PCR. However, the odds of a positive PCR for Animals 1 and 2 were at least 13.6 e 9.11 greater comparing with animals 3-6, respectively. PCR-positive areas were more likely to be found in Animals 1 and 2 compared with the other Animals $(P<0.001)$. CNS region 1 contained more PCR-positive areas than CNS region $2(P<0.02)$, and the odds of containing a positive PCR (CI=1.13-11.0) result in region 1 were 3.53 times greater than in region 2 . The 159-bp PCR product was confirmed as a partial BHV-5gC sequence. All brain sections were positive for the control $\beta$-actin PCR. The odds of a positive IHC or PCR result were greater for animals with neurological signs than the odds for asymptomatic animals $(P<0.05)$. Poor agreement between the IHC and PCR results (positive or negative) was observed $(\kappa=0.15)$.

\section{DISCUSSION}

Nonsuppurative meningoencephalitis was verified in all of the animals in this study, and has been commonly described in natural (Belknap et al. 1994, Rissi et al. 2008) and experimental (Meyer et al. 2001) cases of BHV-5 infection. The most prevalent lesions (i.e., mononuclear perivascular cuffing and edema) observed in this study are consistent with previous reports of natural or experimental BHV-5 infection in cattle (Ely et al. 1996, Meyer et al. 2001, Perez 
et al. 2003, Elias et al. 2004, Rissi et al. 2006, Ferrari et al. 2007, Rissi et al. 2008). The absence of lesions in the cervical spinal cord, cerebellum, and Gasserian ganglia has been previously reported (Rissi et al. 2008). However, inflammatory lesions in these areas have been reported in some cases (Ely et al. 1996, David et al. 2007, Lunardi et al. 2009). Some cases of fatal neurological BHV-5 infection resulted in mild or no inflammatory changes (Rissi et al. 2008, Flores et al. 2009).

Although the frontal cortex, thalamus, and basal nucleus contained the most perivascular cuffing, others have not reported differences in the distribution of this lesion (Perez et al. 2002). Edema was the most common finding, corroborating with others studies where the authors suggested that edema could contribute to the development of malacia due to ischemia (Rissi et al. 2006, Rissi et al. 2008).

Neuronal necrosis has been reported in experimental and natural BHV-5 infection (Rissi et al. 2006, Isernhagen et al. 2011). Similar to the present study, neuronal necrosis was also described as a frequent lesion in the cerebral cortex and thalamus (Rissi et al. 2008). The greatest neuronal necrosis was found in Animal 1 (presented with neurological signs) and Animal 2 (found dead), which may be a result of the clinical evolution of both animals. Although clinical signs were not observed in Animal 2, we hypothesize that a short clinical evolution to death may have occurred during the night.

In one study, malacia was associated with fatal cases of BHV-5 infection (Spilki et al. 2006); however, in a different study, malacia was not always present in fatal cases (Perez et al. 2002). In the present study, malacia was observed in the thalamus and frontal and parietal cortices, similar to a previous study (Rissi et al. 2008). Others authors have reported that malacia was more frequent in the cerebral cortex, basal nucleus, and thalamus and less frequent in the brainstem, cerebellum, and cervical spinal cord (Elias et al. 2004). Malacia in the brainstem has been associated with cases of virus reactivation in animals previously affected by polioencephalomalacia caused by sulfur ingestion (David et al. 2007).

The presence of eosinophilic intranuclear inclusion bodies is not consistently reported in experimental (Perez et al. 2002) or natural (Aquino Neto et al. 2009) BHV-5 infections in cattle. Similar to our study, in which 6 out of 7 positive areas with intranuclear inclusion bodies also demonstrated malacia, the presence of intranuclear inclusion bodies has been associated with accentuated inflammation (Colodel et al. 2002, Elias et al. 2004) and areas with malacia (Elias et al. 2004).

In our study, the nonsuppurative meningitis was most commonly classified as mild. Mild or moderate nonsuppurative meningitis has been described in cases of BHV-5 infection in cattle (Lunardi et al. 2009), restricted to the anterior and posterior cerebral cortex (Perez et al. 2002). However, in previous cases of BHV-5 infection this lesion was not reported (Cascio et al. 1999, Colodel et al. 2002). Cases of BHV-5 infection with polymorphonuclear infiltration in the brain have been reported (Elias et al. 2004, Rissi et al. 2006), but this pathological finding was not observed in the present study.
The Gasserian ganglia are an important access point to the nervous system for the virus (Perez et al. 2002); however, lesions at this site are not always present (Rissi et al. 2008). Trigeminal ganglionitis was not observed in the present study, and only one section was positive for BHV-5 using PCR. All of the olfactory bulb sections demonstrated lesions, and three animals (50\%) tested positive for BHV-5 using IHC or PCR. These results suggest that the olfactory bulb may have been the more likely route the virus used to reach the brain in our study. Studies in rabbits have indicated that the olfactory bulb is a more common route for brain infection for BHV-5 than the Gasserian ganglia (Beltrão et al. 2000, Diel et al. 2005, Fonseca et al. 2006).

Despite presenting with inflammatory lesions, clinical abnormalities were not observed in animals $3,4,5$, and 6 . Moderate histopathological changes without evident clinical signs have been previously described in cattle experimentally infected with BHV-5 (Isernhagen et al. 2011) and BHV-5-infected rabbits (Chowdhury et al. 1997). In animals $3,4,5$, and 6, BHV-5 most likely caused infection, spread through the brain and caused nonprogressive and less severe inflammatory changes, which may have prevented neurological signs. The clinical presentation of the disease is related to the neuroinvasiveness and neurovirulence of the BHV-5 strain (Vogel et al. 2003, Vogel et al. 2004, Isernhagen et al. 2011).

The histopathological evaluation indicated that the cerebral cortex, thalamus, olfactory bulb, and basal nucleus contained more severe lesions than other areas. Previous studies have reported evident inflammatory and degenerative lesions in the same areas (Salvador et al. 1998, Meyer et al. 2001, Rissi et al. 2006).

Telencephalon and thalamus had greater mean of the lesions, and probably are the best areas to collect samples for histopathology in cases of suspected BHV-5 infection. Comparing the mean of the lesions of CNS regions 1 and 2, we propose that region 1 (olfactory bulb and telencephalon) are better to collect samples to histological diagnosis than region 2 . We did not find similar analyses in previous reports of experimental or natural BHV-5 infection in calves, but grouping the CNS areas into regions may facilitate the collection of brain samples for practitioners. In our experience, lesions in natural cases of BHV-5 meningoencefalitis were more severe than in experimentally infected animals, and probably collecting telencephalic areas will increase the chances of a final diagnosis.

IHC using the gC-specific $2 \mathrm{~F} 9$ monoclonal antibody (Vogel et al. 2003, Oldoni et al. 2004, Hübner et al. 2005) is highly specific as the antibody reacts only to the targeted protein and demonstrates no immunostaining in uninfected calf brains. In a previous study (Meyer et al. 2001) 7 of 8 experimentally infected calves presented with neurological signs and similar histopathological changes, but only 5 calves were IHC positive. In the present, study all of the animals presented with at least 2 IHC-positive areas. While a greater percentage of positive areas $(54.1 \%)$ than our study $(32.4 \%)$ were previously reported (Meyer et al. 2001), there were important differences between these two reports, including the age of the infected animals, the 
primary antibody used, and the BHV-5 strain. Nevertheless, as previously described (Meyer et al. 2001), there was no apparent distribution pattern of the IHC-positive areas in the CNS of infected calves. Moreover, comparing the number of IHC-positive areas, Animal 1 (with neurological sings) had a greater number of positive areas than the others animals $(P<0.05)$. The areas of brain tissue with severe histopathologic lesions were more likely to be positive for the BHV-5 antigen (Belknap et al. 1994, Meyer et al. 2001), which corroborating with our data where IHC-positive areas had greater mean of lesions than IHC-negative areas.

In the present study, $100 \%$ of the animals and $35.1 \%$ of the brain sections tested positive for BHV-5 using PCR. Similar studies with experimentally infected calves using DNA extracted from formalin-fixed, paraffin-embedded brain tissue detected 32.8\% (Arruda et al. 2010), 33.3\% (Pedraza et al. 2010) 66.6\% (Gomes et al. 2002), 75\% (Ferrari et al. 2007) and $87.5 \%$ (Ely et al. 1996) of the positive animals using PCR, multiplex PCR, or nested PCR. Similar to our results, but using DNA extracted from frozen tissue, $100 \%$ of the BHV-5-positive animals using semi-nested PCR (Claus et al. 2005) and PCR (Isernhagen et al. 2011) were reported.

Previous studies have characterized the distribution of BHV-5 DNA in the CNS of cattle. Some authors (Meyer et al. 2001) identified $100 \%$ of BHV-5-positive areas using PCR with only 5 areas of brain tissue from 3 animals, whereas BHV-5 DNA was detected in $62.9 \%$ of the 108 analyzed areas from 9 experimentally infected calves (Vogel et al. 2003) and in $67.1 \%$ of 70 areas from 7 animals (Isernhagen et al. 2011). All of these studies used DNA extracted from frozen tissue and demonstrated that the BHV-5 DNA could not be detected with a specific distribution pattern. However, based on the PCR results of CNS regions 1 and 2, the olfactory bulb and telencephalon (region 1) were better for the collection of field samples with a probable diagnosis of BHV-5 infection by PCR.

We hypothesize that the different origins of the extracted DNA (e.g., frozen and FFPE tissue), age and breed of the animals, and BHV-5 strain could explain the discrepancies in the PCR results in our study and previously published studies.

PCR-positive areas contained more lesions than PCR-negative areas. It could be useful to choose which FFPE areas should be used for DNA extraction and PCR analysis. Since telencephalon and thalamus had greater mean of the lesions they probably could be targeted areas to collect samples for PCR. We were not able to find any previously published studies to compare these results with.

The animals with neurological signs contained more PCR- and IHC-positive areas than the other animals. This result is consistent with previous study, who reported that $85 \%$ and $43 \%$ of the areas in animals with and without neurological signs were PCR-positive for BHV-5, respectively.

In our study, poor agreement was observed between the IHC and PCR results ( $\kappa=0.15)$. To date, no other data regarding these results have been published. The positive areas identified using PCR were sometimes IHC negative.
However, the IHC test used in this study is based on the antibody-mediated recognition of BHV-5 gC, which will not be present if the virus has already entered into latency. Therefore, these results support the use of PCR to maximize the detection sensitivity.

In conclusion, Animals with neurological signs presented more lesions and were more likely to be positive in PCR and IHC. Besides, based on histopathological, PCR, and IHC results, we assume that telencephalon probably is the best sampling area to perform the final diagnosis of BHV-5 meningoencephalitis.

Acknowledgements.- To Dr. Ana Claudia Gorino and Dr. Mariana Fontanetti Marinheiro for their help in animal monitoring and sample collection. We also would like to thank the Virology Laboratory of the Universidade Federal de Santa Maria, Santa Maria, RS, Brazil, for providing the 2F9 antibody, and to thank Profa. Renée Laufer-Amorim.

Declaration of conflicting interests.- The author(s) declared no potential conflicts of interest with respect to the research, authorship, and/or publication of this article.

Funding.- The first author received a scholarship from Fundação de Amparo a Pesquisa do Estado de São Paulo (FAPESP - 2008/07697-9). AAA, JPAJr, RLA, and ASB are recipients of CNPq fellowships.

\section{REFERENCES}

Aquino Neto H.M., Carvalho A.U., Facury Filho E.J., Ferreira P.M., Barbosa-Stancioli E.F., Lobato Z.I.P., Alvarenga M.R., Serrano A.L., Martins R.A. \& Afonso D.A.F. 2009. Meningoencefalite por Herpesvirus bovino $5 \mathrm{em}$ Minas Gerais: relato de caso clínico. Arq. Bras. Med. Vet. Zootec. 61:1-5.

Arruda L.P., Nakazato L., Dutra V., Lemos R.A.A., Nogueira A.P.A., Cruz R.A.S., Pescador C.A. \& Colodel E.M. 2010. Detecção molecular de herpesvírus bovino 1 e 5 em amostras de encéfalo conservadas em formol e emblocadas em parafina provenientes de bovinos com doença neurológica. Pesq. Vet. Bras. 30:646-650.

Barros C.S.L., Driemeier D., Dutra I.S. \& Lemos R.A.A. 2006. Doenças do Sistema Nervoso de Bovinos no Brasil. Agnes, São Paulo, p.166-171.

Belknap E.B., Collins J.K., Ayers V.K. \& Schultheiss P.C. 1994. Experimental-Infection of Neonatal Calves with Neurovirulent Bovine Herpesvirus Type-1.3. Vet. Pathol. 31:358-365.

Beltrão N., Flores E.F., Weiblen R., Silva A.M., Roehe P.M. \& Irigoyen L.F. 2000. Infecção e enfermidade neurológica pelo herpesvírus bovino tipo 5 (BHV5): coelhos como modelo experimental. Pesq. Vet. Bras. 20:144-150.

Cascio K.E., Belknap E.B., Schultheiss P.C., Ames A.D. \& Collins J.K. 1999. Encephalitis induced by bovine herpesvirus 5 and protection by prior vaccination or infection with bovine herpesvirus 1. J. Vet. Diagn. Invest. 11:134-139.

Chowdhury S.I., Lee B.J., Mosier D., Sur J.H., Osorio F.A., Kennedy G. \& Weiss M.L. 1997. Neuropathology of bovine herpesvirus type 5 (BHV-5) meningo-encephalitis in a rabbit seizure model. J. Comp. Pathol. 117:295310.

Claus M.P., Alfieri A.F., Folgueras-Flatschart A.V., Wosiacki S.R., Medici K.C. \& Alfieri A.A. 2005. Rapid detection and differentiation of bovine herpesvirus 1 and 5 glycoprotein $C$ gene in clinical specimens by multiplex-PCR. J. Virol. Methods 128:183-188.

Colodel E.M., Nakazato L., Weiblen R., Mello R.M., Silva R.R.P., Souza M.A., Oliveira Filho J.A. \& Caron L. 2002. Meningoencefalite Necrosante em Bovinos causada por Herpesvírus Bovino o Estado de Mato Grosso, Brasil. Ciência Rural 32:293-298.

Cunha P.H.J. 2010. Polioencefalomalacia experimentalmente induzida pela ingestão de dieta com alto teor de enxofre ou pelo Herpesvírus Bovino 5 em Bovinos. PhD thesis, Department of Veterinary Clinical Science, Univ. Estadual Paulista, Botucatu, SP. 128p. 
David N., Hübner S.O., Riet-Correa F., Halfen D. \& Lemos R.A. 2007. Reactivation of latent bovine herpesvirus type 5 in cattle with polioencephalomalacia induced by ammonium sulphate. Pesq. Vet. Bras. 27:435-441.

Diel D.G., Fonseca E.T., Souza S.F., Mazzanti A., Bauermann F., Weiblen R. \& Flores E.F. 2005. 0 Herpesvírus bovino tipo 5 (BoHV-5) pode utilizar as rotas olfatória ou trigeminal para invadir o sistema nervoso central de coelhos, dependendo da via de inoculação. Pesq. Vet. Bras. 25:164-170.

Elias F., Schild A.L. \& Riet-Correa F. 2004. Meningoencefalite e encefalomalacia por Herpesvírus bovino-5: distribuição das lesões no sistema nervoso central de bovinos naturalmente infectados. Pesq. Vet. Bras. 24:123-131.

Ely R.W., D’Offay J.M., Ruefer A.H. \& Cash C.Y. 1996. Bovine Herpesviral Encephalitis: A Retrospective Study on Archived Formalin-Fixed, Paraffin-Embedded Brain Tissue. J. Vet. Diagn. Invest. 8:487-492.

Ferrari H.F., Luvizotto M.C., Rahal P. \& Cardoso T.C. 2007. Detection of bovine Herpesvirus type 5 in formalin-fixed, paraffin-embedded bovine brain by PCR: a useful adjunct to conventional tissue-based diagnostic test of bovine encephalitis. J. Virol. Methods 146:335-340.

Flores E.F., Weiblen R., Vogel F.S.F., Dezengrini R., de Almeida S.R., Spilki F.R. \& Roehe P.M. 2009. Experimental neuropathogenesis of bovine herpesvirus 5 infection in rabbits. Pesq. Vet. Bras. 29:1-16.

Fonseca E.T., Diel D.G., Souza S.F., Mazzanti A., Weiblen R. \& Flores E.F. 2006. Ablação cirúrgica dos bulbos olfatórios em coelhos: modelo para estudos de patogenia de infecções por vírus neurotrópicos. Ciência Rural 36:544-549.

Franco A.C. \& Roehe P.M. 2007. Herpesviridae, p.435-488. In: Flores E.F. (Ed.), Virologia Veterinária. Ediora da UFSM, Santa Maria, Brazil, p.435488.

Gomes L.I., Rocha M.A., Costa E.A., Lobato Z.I.P., Mendes L.C.N., Borges A.S., Leite R.C. \& Barbosa-Stancioli E.F. 2002. Detecção de herpesvírus bovino 5 (BoHV-5) em bovinos do Sudeste Brasileiro. Arq. Bras. Med. Vet. Zootec. 54:217-220.

Hübner S.O., Pescador C., Corbellini L.G., Driemeier D., Spilki F.R. \& Roehe P.M. 2005. Otimização da imunoistoquímica para detecção de herpesvírus bovino tipo 5 (BHV-5) em tecidos do sistema nervoso central fixados com formaldeído. Arq. Bras. Med. Vet. Zootec. 57:1-6.

Isernhagen A.J., Cosenza M., da Costa M.C., Medici K.C., Balarin M.R., Bracarense A.P., Alfieri A.A. \& Lisboa J.A. 2011. Asymptomatic encephalitis in calves experimentally infected with bovine herpesvirus-5. Can. Vet. J. 52:1312-1318.

Lunardi M., Claus M.P., Lisbôa J.A.N., Amude A.M., Headley S.A., Alfieri A.F. \& Alfieri A.A. 2009. Neurological and epidemiological aspects of a BoHV5 meningoencephalitis outbreak. Braz. Arch. Biol. Technol. 52:77-85.

Meyer G., Lemaire M., Ros C., Belak K., Gabriel A., Cassart D., Coignoul F., Belak S. \& Thiry E. 2001. Comparative pathogenesis of acute and latent infections of calves with bovine herpesvirus types 1 and 5 . Arch. Virol. 146:633-652.

Oldoni I., Weiblen R., Inkelmann M.A. \& Flores E.F. 2004. Production and characterization of monoclonal antibodies to a Brazilian bovine herpesvirus type 5. Braz. J. Med. Biol. Res. 37:213-221.
Pedraza F.J., Alessi A.C. \& Barbosa-Stancioli E.F. 2010. Detection of bovine herpesvirus 5 (BoHV-5) in formalin-fixed, paraffin-embedded bovine brain by nested PCR in Colombian cattle. Revta. Colomb. Cienc. Pecu. 23:292-298.

Perez S.E., Bretschneider G., Leunda M.R., Osorio F.A., Flores E.F. \& Odeon A.C. 2002. Primary infection, latency, and reactivation of bovine herpesvirus type 5 in the bovine nervous system. Vet. Pathol. 39:437-444.

Perez S.E., Vagnozzi A., Sur J.H., Odriozola E., Campero C.M. \& Odeon A.C. 2003. Analisis retrospectivo de casos con diagnostico de necrosis cerebrocortical y su relacion con herpesvirus bovino tipo 5. Revta Argent. Microbiol. 35:69-73.

Rissi D.R., Oliveira F.N., Rech R.R., Pierezan F., Lemos R.A.A. \& Barros C.S.L. 2006. Epidemiologia, sinais clínicos e distribuição das lesões encefálicas em bovinos afetados por meningoencefalite por herpesvírus bovino-5. Pesq. Vet. Bras. 26:123-132.

Rissi D.R., Pierezan F., Silva M.S., Flores E.F. \& Barros C.S.L. 2008. Neurological disease in cattle in southern Brazil associated with Bovine herpesvirus infection. J. Vet. Diagn. Invest. 20:346-349.

Roizmann B., Desrosiers R.C., Fleckenstein B., Lopez C., Minson A.C. \& Studdert M.J. 1992. The family Herpesviridae: an update. The Herpesvirus Study Group of the International Committee on Taxonomy of Viruses. Arch. Virol. 123:425-449.

Sá e Silva M., Brum M.C.S., Weiblen R. \& Flores E.F. 2007. Identificação e diferenciação de herpesvírus bovino tipos 1 e 5 isolados de amostras clínicas no Centro-Sul do Brasil, Argentina e Uruguai (1987-2006). Pesq. Vet. Bras. 27:403-408.

Salvador S.C., Lemos R.A.A., Riet-Correa F., Roehe P.M. \& Osório A.L.A.R. 1998. Meningoencefalite em bovinos causada por herpesvírus bovino-5 no Mato Grosso do Sul e São Paulo. Pesq. Vet. Bras. 18:76-83.

Sant'Ana F.J.F., Rissi D.R., Lucena R.B., Lemos R.A.A., Nogueira A.P.A. \& Barros C.S.L. 2009. Polioencefalomalacia em bovinos: epidemiologia, sinais clínicos e distribuição das lesões no encéfalo. Pesq. Vet. Bras. 29:487-497.

Souza V.F., Melo S.V., Esteves P.A., Schmidt C.S., Gonçalves D.A., Schaefer R., Silva T.C., Almeida R.S., Vicentini F., Franco A.C., Oliveira E.A., Spilki F.R., Weiblen R., Flores E.F., Lemos R.A., Alfieri A.A., Pituco E.M. \& Roehe P.M. 2002. Caracterização de herpesvírus bovinos tipos 1 (BHV-1) e 5 (BHV5) com anticorpos monoclonais. Pesq. Vet. Bras. 22:13-18.

Spilki F.R., Silva T.C., Esteves P.A., Teixeira M.B., Batista H.B.C.R., Chiminazzo C., Driemeier D., Franco A.C. \& Roehe P.M. 2006. Co-infections with bovine herpesvirus type 5 and bovine viral diarrhoea virus. Arq. Bras. Med. Vet. Zootec. 58:699-707.

Vogel F.S.F., Caron L., Flores E.F., Weiblen R., Winkelmann E.R., Mayer S.V. \& Bastos R.G. 2003. Distribution of Bovine Herpesvirus Type 5 DNA in the Central Nervous Systems of Latently, Experimentally Infected Calves. J. Clin. Microbiol. 41:4512-4520.

Vogel F.S.F., Lima M., Flores E.F., Weiblen R., Winkelmann E.R., Mayer S.V., Mazzutti K.C. \& Arenhart S. 2004. Replicação e excreção viral durante a infecção aguda e após a reativação da latência induzida por dexametasona em bezerros inoculados com os herpesvírus bovinos tipo 1 (BHV-1) e 5 (BHV-5). Ciência Rural 34:1619-1621.

\section{ERRATA}

In the paper "Histopathological, immunohistochemical, and molecular study of BHV-5 infection in the central nervous system of experimentally infected calves", published at Pesquisa Veterinária Brasileira, v.35, n.4, p.337-343, 2015, DOI: 10.1590/S0100-736X2015000400004, on page 337, where it reads:

"Renée Laufer-Amorim"”,

it should read:

"Amauri A. Alfieri5".

In the same paper, on page 342 , where it reads:

"Dr. Amauri A. Alfieri for providing the BHV-5 AA PAR strain.",

it should read:

"Profa. Renée Laufer-Amorim." 